\title{
The 2018 eruption of Kīlauea and assessments of volcanic hazard
}

\author{
DONALD A. SWANSON ${ }^{1}$
}

1417 Linaka Street, Hilo, HI 96720

Lava flows from the $\sim 3$-month-long 2018 Killauea eruption covered $35.65 \mathrm{~km}^{2}$, destroyed 723 homes and isolated 65 others, and resulted in monetary losses of $>500$ million dollars. Part of the summit of the volcano, $40 \mathrm{~km}$ away from the site of eruption, collapsed $>500 \mathrm{~m}$, generated more than 45,000 earthquakes (many felt), and raised the frightening specter of powerful explosions, though fortunately none occurred. The public was kept informed by USGS, Hawai'i County Civil Defense, and National Guard, aided by FEMA and university scientists, through community meetings, webpages, and social media. A triumph of this interaction is that no fatalities and only one serious injury resulted, though nothing could be done to halt the destruction of property and infrastructure. Access roads are now being reestablished across the lava flows to enable residents to return to their properties. Parts of the summit of Killauea, in Hawai'i Volcanoes National Park, are now open to visitors, and other parts will be soon. Society is slowly and painfully returning to normal, but memories of 2018 will be long lasting.

Public awareness of volcanic hazards at Kīlauea was raised in 2014-2015, when the village of Pāhoa was threatened by a long lava flow from $\mathrm{Pu}^{\prime} \mathrm{u}$ ' $\overline{\mathrm{O}}$ ' $\mathrm{o}$. That 'prelim' was helpful in gaining public understanding as the 2018 events unfolded. Most other volcanoes in the world lack the 'luxury' of frequent eruptions to maintain public awareness. At such volcanoes, it is all the more important to maintain a running dialog among scientists, government officials, and the public, though it is a hard sell to foster interest when eruptions are uncommon.

The foundation of informing the public is knowledge of what the volcano can do. Research is the means for increasing this knowledge. The accuracy of public statements can only be improved by knowing more about the volcano. Thus, research into volcanic processes and history is fundamental for improving public safety and should be conducted both before and during an eruption crisis. It is sometimes difficult to convince crisis managers that time-critical research must be done in areas closed to the general public. Dialog between scientists and land managers before the crisis unfolds helps, but still we probably have to accept that there will be times when conflict arises. 